\title{
AN OVERVIEW OF HISTORIOGRAPHICAL EDITIONS PUBLISHED BY MATICA HRVATSKA (1918-1996)
}

\author{
Stipe KLJAIĆ*
}

This article focuses on the historiographical editions published by Matica Hrvatska from 1918 to the first half of the 1990s, which influenced the formation of Croatia's intellectual and cultural identity over a period of almost a century. Historiographical editions have been chronologically divided into three significant periods of their publication, which correspond to important historical and political epochs: the first period being from the dissolution of the $\mathrm{Au}-$ stro-Hungarian Monarchy and the entry of the Croatian people into the first Yugoslav state in 1918 to the collapse of the Independent State of Croatia in 1945; the second from the establishment of the second Yugoslavia until its disintegration, from 1945 to 1989; and the third from the beginning of the democratic changes in 1990 and the creation of the present Croatian state. The article shows that the works published by Matica mirrored in many ways the political aspirations of each epoch, as has been amply documented in this article. The historiographical editions published by Matica Hrvatska during the $20^{\text {th }}$ century undoubtedly reflect various political and social changes that influenced the publishing policy of this oldest Croatian cultural institution. Its publishing activity experienced a particular boom during the presidency of Filip Lukas between 1928 and 1945 , which is certainly one of the most productive periods in the history of Matica in terms of publishing and of cultural promotion. Unlike the socialist period, when national themes were suppressed and avoided in a certain way, and there were almost no publications on local history, in the said period Matica not only focused on national history, but also printed numerous editions dealing with the local histories of individual Croatian cities and regions. The most se-

* Stipe Kljaić, Ph. D., Croatian Institute of History, Zagreb, Croatia. 
rious crisis in Matica's history came after World War II, when its publishing activities were suppressed, primarily because of its previous role in promoting Croatian nationalism. Its membership had given strong support to the establishment of the Croatian state in 1941, which in no way coincided with the overall direction of the cultural policy of the post-war communist regime. In this regard, the pinnacle was the eventual ban on Matica's work, which came in 1972 because of its prominent role in the Croatian Spring during the 1960s, until the dismissal of the Croatian communist leadership in Karadorđevo in 1971. In such circumstances, Matica's publishing activity barely managed to survive in the framework of Matica Hrvatska's Publishing House. This institute pursued particularly extensive publishing activity in the years when the Yugoslav communist system began to disintegrate, in 1989-1990, when it also published the works of the former dissident and future Croatian President, Franjo Tuđman. In the aftermath of the establishment of a democratic Croatian state and with the renewal of Matica's work, its publishing activity experienced a resurgence towards the end of the $20^{\text {th }}$ century, when topics from national and local history were again in its focus, as well as the previously banned books of the emigration, now published in new, Croatian editions.

Keywords: Matica Hrvatska, historiography, publishing, $20^{\text {th }}$ century

\section{Historiographical editions 1918-1945}

At the beginnings of the common state with Slovenes and Serbs just after 1918, Matica Hrvatska already indicated that, as a leading cultural institution, it might find itself in opposition to the official ideology and politics of the royal Yugoslav regime. This course was already struck in 1925 by its future president, geographer and historian Filip Lukas, during whose presidency Matica would become one of the main opposition strongholds in Croatia against the Belgrade regime in the 1930s. Thus, just a few years after the establishment of the Yugoslav state, on the occasion of the great $1000^{\text {th }}$ anniversary of the Croatian kingdom in 1925, Filip Lukas wrote a special edition of a booklet on Strossmayer's experience of political Croatism: Strossmayer i hrvatstvo [Strossmayer and Croatism]. Lukas' analysis showed that disappointment in Yugoslav identity manifested itself very quickly in most of the Croatian intelligentsia after the establishment of the Yugoslav state. His argument was intended to indicate that Strossmayer's view of Yugoslavia was being too easily appropriated for daily political purposes, in order to promote the ruling Yugoslav nationalism. Apart from its historical character, his study also carried the political connotations of the time, since Lukas opposed the ideological constructs of that 
time such as the hypothesis that the Bishop of Đakovo had been "the apostle of Yugoslavism." Lukas made this clear when stating that Strossmayer had never denied the Croatian state law, as those who later invoked his Yugoslavism did, making him the spiritual founder of the Yugoslav state. He thus quoted the Bishop of Đakovo "calling the Croatian state law in one of his treatises an essential part of the public law of legitimate Europe." Lukas therefore clearly showed that Strossmayer's Yugoslavism was a "cultural notion" rather than a "state-legal and national-social" one, and that as such, "it was not intended to deny the historical names of the Yugoslav peoples." In a sense, Lukas wanted to portray Strossmayer in the light of his own political beliefs at the time, namely as one who would have been willing to accept the Yugoslav state, but only on condition that it be organized on federalist grounds.

The central event of this period in terms of Matica's historiographical production was a representative volume edited by Lukas on the millennium of the Croatian Kingdom, which came out in 1925 as Book I and Volume I, as its editors planned to continue the series. However, further volumes never saw the light of day. The most likely reason was the political crisis that followed shortly afterwards, with the assassination of Stjepan Radic and his associates in 1928, and the subsequent proclamation of Alexander I Karađorđević's dictatorship on January 6, 1929. ${ }^{2}$ Apart from Lukas, contributors to the volume included Vjekoslav Klaić, Frane Bulić, and Josip Nagy. The full title was: Zbornik Matice hrvatske. Hrvatskom narodu, njegovim prošlim naraštajima na spomen, sadašnjima i budućima na pobudu o tisućoj godišnjici hrvatskoga kraljevstva [Proceedings of Matica Hrvatska: To the Croatian People, to Commemorate Its Past Generations and Inspire the Present and Future Ones, on the Thousandth Anniversary of the Croatian Kingdom]. The authors and articles were as follows: Vjekoslav Klaić ("National Assembly and the Crowning of Kings in Duvanjsko Polje; The Croatian Parliament before 1790"), Filip Lukas (“The Geographical Foundations of the Croatian People"), Don Frane Bulić ("Development of Archaeological Research and Scholarship in Dalmatia over the Past Millennium"), and Josip Nagy ("Croatian Documents from the Time of the National Dynasty"). ${ }^{3}$

While the articles by Klaić, Bulić, and Nagy took a medievalist and archaeological perspective, Lukas spoke from the aspect of the geographical framework in which the Croatian history had been unfolding. In the first part of his article, Lukas wrote about the territory, while in the second he focused on

\footnotetext{
Filip Lukas, Strossmayer i hrvatstvo (Zagreb: Matica Hrvatska, 1925), pp. 17 and 20.

2 Ive Mažuran and Josip Bratulić, Spomenica Matica hrvatska 1842.-2002. [History of Matica Hrvatska, 1842-2002] (Zagreb: Matica Hrvatska, 2004), p. 139.

$3 \quad$ Filip Lukas, Zbornik Matice hrvatske: Hrvatskom narodu, njegovim prošlim naraštajima na spomen, sadašnjima i budućima na pobudu o tisućoj godišnjici hrvatskoga kraljevstva (Zagreb: Matica hrvatska, 1925).
} 
the issue of nationality, where he made clear that "the Croats are a people, not a tribe" as advocated by the official ideology of the Kingdom of SHS in the 1920 s. ${ }^{4}$ In addition to his study on the crowning of kings in Duvanjsko Polje, Klaić published another on the work of the Croatian Parliament until 1790. His attempt to revive the public memory of the history of the Croatian Parliament also reflected the current political circumstances, in which the ancient institution of Croatian statehood no longer existed. Therefore, Klaić emphasized in the very introduction to his article that "no other institution of public life reflects as vividly and emphatically the sovereignty and self-determination of any people, as do its state assemblies or parliaments."

In the 1920s, Matica Hrvatska also published studies by Ferdo Šišić in which he presented the original historical sources and documentation relevant for the establishment of the first Yugoslav state. They were published two years after the unification, in 1920, under the title Dokumenti o postanku Kraljevine Srba, Hrvata i Slovenaca [Documents on the Formation of the Kingdom of Serbs, Croats, and Slovenes], referring to the period 1914-1919. Šišić noted that the archives of the National Council of SHS in Zagreb had been de facto alienated and that the rich material relevant to the establishment of the Yugoslav state preserved by the diplomatic missions of the Entente states, and in the archives of the Serbian and former Montenegrin governments, were not available to him. For this reason, he hoped that the available material published in this form would encourage those who witnessed the preparation of the common state of South Slavs to write their memoirs in order to compensate to some extent for the insufficiency of archival sources. ${ }^{6}$ Many did not respond to Šišićs invitation primarily because such an act was by no means opportune in the situation of the ubiquitous political crisis of the Yugoslav project. One should also keep in mind that a considerable number had meanwhile changed their political beliefs. The same historian attached to his original material another collection of documents, titled Jadransko pitanje na Konferenciji mira u Parizu [The Adriatic Question at the Paris Peace Conference]. His motivation behind writing on this issue was its relevance at the time, since the Adriatic question had been in the focus of international politics ever since the secret Treaty of London in 1915, as well as its post-war reality, since in 1920 a good part of Dalmatia was under Italian occupation. ${ }^{7}$

At that time, Matica published three studies on medieval history, written by historians Gjuro Szabo and Emil Laszowski. In 1920, Szabo extensive-

\footnotetext{
$4 \quad$ Lukas, Strossmayer i hrvatstvo, p. 82.

5 Vjekoslav Klaić, "Hrvatski sabori do godine 1790." in Zbornik Matice hrvatske, p. 249.

6 Ferdo Šišić, Dokumenti o postanku Kraljevine Srba, Hrvata i Slovenaca, 1914.-1919. (Zagreb: Matica hrvatska 1920), pp. 1-2.

7 Ferdo Šišić, Jadransko pitanje na Konferenciji mira u Parizu (Zagreb: Matica hrvatska, 1920).
} 
ly explored the Medieval Towns in Croatia and Slavonia, in a scholarly booklet aimed at "showing that the ruins of our towns cannot be an object of romantic daydreaming, but are there for us to learn about the function of these buildings, to learn how these piles of stones are witnesses to the lives of generations long gone, and without their efforts, our present cultural situation would not

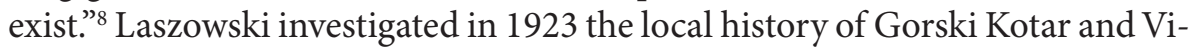
nodol under the noble families of Zrinski and Frankopan, continuing the work of his role model, Professor Radoslav Lopašić, who had already written on certain Croatian regions (Bihać i bihaćka krajina: Oko Kupe i Korane [Bihać and the Bihać Region: Around the Kupa and Korana Rivers]). ${ }^{9}$ Laszowski also offered Matica a history of the Zagorje region for publication, but that book never saw the light of day. ${ }^{10}$

A particularly valuable work for the study of Croatian medieval past is that of Kerubin Šegvić, written in 1927 and published by Matica: a historical account of the life and work of Thomas the Archdeacon, author of the famous Historia Salonitana. In his opening remarks, Šegvić reveals what motivated him to write about Thomas, namely the inaccurate accusations and confabulations that the Archdeacon was "an advocate of Latin liturgy and an enemy of the Croats," as claimed by the representatives of "Yugoslavizing" historiography, "who disliked his political and state-related observations." In addition, both Kršnjavi and Selem, Šegvić notes, "misrepresented and partly misinterpreted Thomas' personality in their short monograph study printed in Rivista Dalmatica in 1925, so it was necessary to put it in the right light," all of which was a reason for Šegvić to focus on Thomas in his 1927 study. ${ }^{11}$ Šegvićs undertaking, as well as the aforementioned one of Filip Lukas, show the manifest dissatisfaction of the Croatian intelligentsia with the situation in the new common Yugoslav state, when the oldest Croatian past was supressed in the name of creating Yugoslav traditions.

In 1924 (given as 1923), Matica Hrvatska published in three volumes the work of the then Full Professor of General History of Antiquity at the Faculty of Arts and Social Sciences, and the later President of the Yugoslav Academy of Sciences and Arts (JAZU) from 1924 to 1933, Gavro Manojlović (18561939): Povijest staroga Orijenta do 11. stoljeća prije Krista [History of the Ancient Orient until the $11^{\text {th }}$ Century $\left.B C\right]$. This crown of his work on the subject appeared exactly forty years after his translation of Gaston Maspero's Povijest

\footnotetext{
Gjuro Szabo, Sredovječni gradovi Hrvatske i Slavonije (Zagreb: Izvanredno izdanje Matice hrvatske, 1920), p. 1.

9 Emil Laszowski, Gorski kotar i Vinodol [Gorski kotar and Vinodol] (Zagreb: Matica hrvatska, 1923).

10 Mažuran - Bratulić, Spomenica Matica hrvatska, p. 139.

11 Kerubin Šegvić, Toma Archiđakon i njegovo djelo [Thomas the Archdeacon and his work] (Zagreb: Matica hrvatska, 1927), p. 1.
} 
istočnih naroda u Starom vijeku [Ancient History of the Eastern Peoples], likewise published by Matica. It was the first attempt in Croatian historiography to produce a synthesis of the history of the ancient Orient, its importance not diminished by the fact that it did not make any significant scientific advances as it was written on the basis of German literature. ${ }^{12}$

It is worth mentioning another book from the field of historiography and political sciences, written by Vinko Lozovina, an expert on Italian language and literature, high-school teacher in Split, and literary historian, for the $400^{\text {th }}$ anniversary of Machiavelli's death in 1928. This study had been the greatest contribution by that time to the knowledge of Machiavelli's political thought in the Croatian language besides a 1918 translation of his Vladar [Prince], to which Lozovina wrote a foreword. He admitted that he had become interested in the work of the founder of modern political science under the impression of fierce party and national struggles that dominated the first decade of the SHS Kingdom. For this purpose, he wanted to introduce Machiavelli's political philosophy to the Croatian public, as he had engaged with the political debates of his time with great passion. ${ }^{13}$

Niko Bjelovučić, a historian of Dubrovnik, published his book Crvena Hrvatska i Dubrovnik [Red Croatia and Dubrovnik] in 1929, outlining the archaeological and historical material on the medieval Croatian state in the area of the Dubrovnik Republic and Bay of Kotor, which had once extended all the way to the Bojana River. In 1929, the first year of Alexander's dictatorship, Bjelovučić wrote: "I have paid particular attention to proving by historical evidence that in the $10^{\text {th }}$ century, the Croatian state extended to the Bojana River." ${ }^{14}$ Bjelovučić's research shows a striking discontinuity with regard to the Croatian medieval studies on Red Croatia that appeared after 1945. Namely, at that time it was no longer mentioned or explored, which certainly had to do with the new borders drawn by AVNOJ, when Bay of Kotor became part of the People's Republic of Montenegro, as well as with political control exerted over historiographical work, to which the opportunism of historians on this historical issue contributed as well.

When Filip Lukas took over Matica Hrvatska in 1928, it became a firm stronghold against the Greater Serbian regime in Belgrade, which persisted in dictatorship under the cover of Yugoslavism. Lukas squeezed out the previous president, Albert Bazal, who was negotiating in Novi Sad without Matica's board about the possibility of merging Zagreb's and Novi Sad's Matica into

\footnotetext{
12 Gavrlo Manojlović, Povijest starog Orijenta do XI. stoljeća, vol. 1 (Zagreb: Matica hrvatska, 1923).

13 Vinko Lozovina, Niccolo Macchiavelli i njegova politička nauka [Niccolo Machiavelli and his political thought] (Zagreb: Matica hrvatska, 1928), p. 1.

14 Niko Bjelovučić, Crvena Hrvatska i Dubrovnik (Zagreb: Matica hrvatska, 1929), p. 4.
} 
a unified Matica Jugoslavenska. Lukas' sharp political turn had an immediate impact on the publication of historiographical works, so in the midst of dictatorship, in 1930, the second edition of Vjekoslav Klaićs book Hrvati i Hrvatska: Ime Hrvat u povijesti slavenskih naroda [The Croats and Croatia: The Name "Croat" in the History of Slavic Peoples] was published. It was a strong protest against the King's proclamation of "one king, one state, one people" and his banning Croatian "tribal" names and symbols. Klaić had originally published the book in 1899. The foreword to this new, posthumous edition of his study on the name "Croat" was written by historian Josip Nagy, who emphasized that "Klaić ends with the conclusion that the name 'Croat' was known to almost all Slavic peoples, that the names of other Slavic tribes were not as widespread as this one, and that it occurs more often than any other name in the Slavic history of the $10^{\text {th }}$ century." ${ }^{15}$ In 1930 , Matica also decided to publish the book Povijest Hrvata u Vojvodini : od najstarijih vremena do 1929. godine [History of the Croats in Vojvodina: From the Earliest Times until 1929] by Petar Pekić (18961965), a historian of the Vojvodinian Croats, in the circumstances when the royal regime tried to portray the Šokci and the Bunjevci in that region as mere tribes within the single and unified Yugoslav people. ${ }^{16}$

At the beginning of the 1930s, Milutin Cihlar Nehajev published two significant editions for the $60^{\text {th }}$ death anniversary of Eugen Kvaternik in 1931 and the $100^{\text {th }}$ anniversary of the Croatian National Revival in 1932. At that time, there were heated polemics about the Illyrian movement - whether it was to be regarded as pan-Yugoslav, as claimed by the official ideology and its interpreters or, conversely, it was Croatian in character. Regarding this and such dilemmas, Nehajev clearly pointed out that "Illyrianism was, therefore, Croathood in its most powerful essence in those years, which led to the cancellation of any connection with Hungary and to the enormous advance of Croatian sovereignty in 1848." ${ }^{17}$ Don Kerubin Šegvić, after his book on Thomas the Archdeacon, published another biographical description in 1930, this time of Luka Botić from Split, under the title Luka Botić: njegov život i njegova djela [Luka Botić: His Life and Works]. Šegvić approached Botićs life and work as a literary historian, with the awareness that only his friend from the seminary days, Mihovil Pavlinović, had left any significant record and memory of this Split poet. ${ }^{18}$

\footnotetext{
15 Josip Nagy, "Predgovor” [Foreword], in: Vjekoslav Klaić: Ime Hrvat i Hrvatska (Zagreb: Matica hrvatska 1930), p. 12.

16 Petar Pekić, Povijest Hrvata u Vojvodini: od najstarijih vremena do 1929. godine (Zagreb: Matica hrvatska, 1930).

17 Milutin Cihlar Nehajev, O stogodišnjici hrvatskog narodnog preporoda (1830.-1930.) [To the 100th anniversary of the Croatian National Revival (1830-1930)] (Zagreb: Mala knjižnica Matice hrvatske, 1931), p. 23.

18 Kerubin Šegvić, Luka Botić: njegov život i njegovo djelo (Zagreb: Matica hrvatska, 1930), pp. $8-9$.
} 
In those years, 1931 and 1932, Bosnian-Muslim historical themes appeared among Matica's publications: a biographical lexicon of the retired curator of the National Museum in Sarajevo, Safvet beg Bašagić (1870-1934) Znameniti Hrvati Bošnjaci i Hercegovci u turskoj carevini [Famous Croats, Bosniaks and Herzegovinians in the Ottoman Empire], or the study of the Croatian historian and archaeologist from Bosnia, Mihovil Mandić (1870-1948), titled Vezirski Travnik nekad i sada [The Travnik of the Viziers, Once and Now]. In his booklet, Bašagić presented an extensive list of prominent figures in the history of the Ottoman Empire who originated from Bosnia and other Croatian countries ruled by the Ottomans. The preface was written by Matica's president Filip Lukas, who viewed the Bosnian Muslims as members of the Croatian people, noting that "the Turkish lordship could not reverse the older circumstances in physical, biological, and linguistic terms." Following Starčevićs opinion, according to which the "famous Croats, Bosniaks, and Herzegovinians in the Ottoman Empire" were an integral part of the Croatian identity, he invoked an old folk saying: "love thy brother, whatever be his religion." ${ }^{19}$

Lukas quoted this saying in the atmosphere of the 1930s, when the Croatian side strove to prove that there was no single Yugoslav nation and that the Muslims were linguistically and physically equal to the Catholic Croats, in order to prove that Bosnia and Herzegovina was predominantly Croatian, rather than Serbian land. Bare Poparić, a priest and historian from Kaštel Novi, published Pregled povijesti pomorstva [An Overview of Maritime History] in two volumes in 1932. ${ }^{20}$ Historian Rudolf Horvat (1873-1947) continued to write about the history of individual Croatian regions on the trail of Laszowski and Lopašić, publishing in 1933, in the book series "Small Library of Matica Hrvatska" a book called Hrvatska podravina, povijesne rasprave, crtice i bilješke [Croatian Podravina: Historical Studies, Sketches, and Notes]. ${ }^{21}$ Josip Horvat wrote a two-volume historical novel dedicated to 1848 as the pinnacle of the Croatian National Revival in the Triune Kingdom for the $100^{\text {th }}$ anniversary of the Revival, based on archival materials. ${ }^{22}$

The aforementioned Vinko Lozovina stood out among the Split intelligentsia as opposed to the Vidovdan Yugoslavia and thus came into conflict with Silvio Alfirević, director of a Split high school and one of the later leaders of the

\footnotetext{
19 Filip Lukas, "Predgovor” [Foreword], in: Safvet beg Bašagić, Znameniti Hrvati Bošnjaci i Hercegovci u turskoj carevini (Zagreb: Matica hrvatska, 1932), pp. 1-2.

20 Bare Poparić, Pregled povijesti pomorstva (Zagreb: Matica hrvatska, 1932).

21 Rudolf Horvat, Hrvatska podravina, povijesne rasprave, crtice i bilješke (Zagreb: Matica hrvatska, 1933).

22 Josip Horvat, Tisuću osamsto četrdeset osma [The year 1848] (Zagreb: Matica hrvatska, 1934).
} 
local Chetnik circle during World War II. ${ }^{23}$ In the Dalmatian milieu, especially among the intelligentsia, there was a persistent sentiment even after 1928 that saw in Dalmatia the state-forming nucleus of Yugoslavia and a corpus separatum with regard to the rest of Croatia. Lozovina decidedly opposed such tendencies and in his reviews of Croatian literary history, he assessed in 1936 in his book on Dalmacija u hrvatskoj književnosti [Dalmatia in Croatian Literature] that "the five strongest writers, Vojnović, Tresić-Pavičić, Nazor, Begović, and Šimunović, who were born and raised in Dalmatia, and evolved after the 1890 s to first-rate artists, are the best proof with what power and breadth Dalmatian regionalism flows into nationalism and Dalmatian regional literature in the general Croatian national literature." In addition, Lozovina portrayed Dalmatia as the cradle of Croatian medieval civilization, emphasizing that "the direct contacts with the Dalmatian Latin population and the great proximity of the West contributed to the fact that these Croats started to receive Christianity before all other Slavs, and with it the germs of a new, spiritual life." In order to stress even further the differences between the Serbs and the Croats, which was a general tendency in the second half of the 1930s, Lozovina also sought to prove the crucial influence of Latinity and the Western world over the Byzantine cultural circle with regard to Dalmatia as the cradle of Croathood. ${ }^{24}$

In an atmosphere of a growing Croatian national movement against the Yugoslav regime, Matica published in 1936 a collection of papers dedicated to the $40^{\text {th }}$ death anniversary of Ante Starčević, followed by a study by Mile Starčević, the then secretary of Matica Hrvatska, on Ante Starčević i Srbi [Dr Ante Starčević and the Serbs]. He pointed out the historical fact that Starčević was the first Croatian politician to warn of the very dangerous theses of Greater Serbian politics and ideology. That is why he considered Garašanin's Načertanije (Programme) as the principal programmatic text of the Greater Serbian political project in the $19^{\text {th }}$ and $20^{\text {th }}$ centuries. On the cultural and educational level, Mile Starčević pointed out that the central premise in the education of the Serbian people in the principality and kingdom of Serbia was Karadžić's claim that "the Croats are only Chakavian, only occasionally Kajkavian, on which the entire official Serbian historiography was built." He recalled Ante Starčević's guidelines for the current situation, saying that "setting aside all daydreams and metaphysical politics, the Croats must work for themselves and based on their history, their nationality, and their public, local, and international law." Concluding his study, Mile Starčević brings the following words

\footnotetext{
$\overline{23}$ Bogdan Radica, Živjeti nedoživjeti - uspomene hrvatskog intelektualca kroz moralnu i ideološku krizu zapada [To live but not experience: Memories of a Croatian intellectual on the moral and ideological crisis of the West], vol. 1 (Munich and Barcelona: Hrvatska revija, 1982), pp. 69-70.

24 Vinko Lozovina, Dalmacija u hrvatskoj književnosti (Zagreb: Matica hrvatska, 1936), pp. 3-4 and 266.
} 
of the politician, which had the force of a message to his contemporaries before the collapse of old Yugoslavia: "the Croatian people must be free and wants to be free, and it is entitled to it like any other people." 25

When publishing a volume of essays on the occasion of Ante Starčevićs $40^{\text {th }}$ death anniversary, Lukas stated that Starčević's ideas were more alive and contemporary than ever before, thus echoing the sentiments of the then intelligentsia gathered around Matica that an independent Croatian state must be created at all costs. At the very end of the text, Lukas sent a message to Vladko Maček that the Croatian people had responded to the peasant movement because it supposed that "Starčević's programme, which is Croatia's independence," would be fulfilled through it. ${ }^{26}$ All this was happening in the context of Lukas' opposition to Maček's cooperation with Belgrade. Šišićs book Kako je došlo do okupacije a onda do aneksije BiH [How It Came to the Occupation and Then Annexation of Bosnia and Herzegovina] did not appear in bookstores due to problems with censorship. Šišićs assessment of the Austro-Hungarian policy towards Bosnia and Herzegovina was that "the annexation of Bosnia and Herzegovina dug a grave to Austria-Hungary, in which it fell head on ten years later (in October 1918)." 27

Emphasizing the Croatian national identity as opposed to the Yugoslav synthesis, Don Lovre Katić from Solin published in 1938 his popular Pregled povijesti Hrvata [Overview of Croatian History]. Thereby he referred to the geopolitical arguments of Pilar and Lukas that the unfavourable geographical position of the Croatian lands had a negative impact on the development of Croatian history. Katićs recourse to the concept of "Croatian national individuality" in his introduction to the book also shows the great preoccupation of Croatian public and political life with the final solution of the Croatian question in the Kingdom of Yugoslavia. ${ }^{28}$ In the same year of 1938, Matica printed Lukas' treatise Problem hrvatske kulture [The Problem of Croatian Culture], in which he tried to challenge the Yugoslav idea intellectually, stating the following: "I have tried in my studies to collect all those objective and subjective moments, and to prove that Croatian nationality is independent and original, and in its identity completely different from any other nationality here in the south, and that therefore the Croatian people has all the rights that belong to it based on national self-determination." 29

\footnotetext{
25 Mile Starčević, Dr. Ante Starčević i Srbi (Zagreb: Matica hrvatska, 1936), pp. 30-31 and 120.

26 Filip Lukas, “Starčević”, in: Zbornik Dr. Ante Starčević o 40. obljetnici smrti (Zagreb: Matica hrvatska, 1936), pp. 8, 28.

27 Ferdo Šišić, Kako je došlo do okupacije a onda do aneksije Bosne i Hercegovine (1878. odnosno 1908.), (Zagreb: Matica hrvatska, 1938), p. 99.

28 Lovre Katić, Pregled povijesti Hrvata (Zagreb: Matica hrvatska, 1938), pp. 3-4.

29 Filip Lukas, Problem hrvatske kulture (Zagreb: Matica hrvatska, 1938), p. 8.
} 
In 1939, after Stalin and Hitler divided Poland among themselves, Aleksander Grabianski published his monograph on Polish history from the Middle Ages to 1920 and the war with Bolshevik Russia. Grabianski took that year as the end point of his research because it was then that Poland's eastern borders were finally established, which led to the creation of a modern Polish state. Evoking the past times, he referred to the current events and emphasized that the crux of Polish medieval history was its "struggle with the German Empire and people over the territory in which the Polish people and state could develop." 30 That same year, Mladen Lorković published his book Narod i zemlja Hrvata [The Croatian People and Country]. Lorković, who had returned from the Ustasha emigration, criticized the territorial framework of the Banate of Croatia without the whole of Bosnia and Herzegovina, reminding the Croatian public that "finally the spiritual inventory of every Croat must include the awareness that one fifth of the Croats are of Islamic religion." He also addressed the Slavic theory on the origin of the Croats, put forward by Franjo Rački and Vatroslav Jagić in the $19^{\text {th }}$ century, who had suggested new theories of origin such as the Iranian-Caucasian theory. ${ }^{31}$ At the same time, the legal historian Antun Dabinović (1882-1964) published his Hrvatska državna i pravna povijest [Croatian Political and Legal History], in which he dealt with the Croatian political and legal tradition from the earliest times until the Cetina Assembly in 1526. Historian Jaroslav Šidak published with Matica his Crkva bosanska i problem bogumilstva u Bosni [Bosnian Church and the Bogomil Issue in Bosnia] in 1940, in which he presented arguments that contradicted those of Vaso Glušac, the chief Serbian researcher of this historiographical problem. Glušac claimed that the Bogomil Church was historically an integral part of the Orthodox Church, while Šidak argued that it had originally belonged to the Catholic Church as the Ecclesia Bosniensis, but that it severed its ties with Rome in the 1230s, adhering to its Cyrilo-Methodian heritage. ${ }^{32}$

Following the breakdown of Yugoslavia and the declaration of the Independent State of Croatia (NDH), the Committee by which Ban Ivan Šubašić exerted his rule over Matica was abolished in 1941. It was then that Matica re-published the work of archaeologist and historian Ćiro Truhelka in which he claimed that the Muslims of Bosnia and Herzegovina were ethnically and linguistically identical with the Catholic Croats. Truhelka's work was to legitimize the new policy of the Ustasha government on the Muslims as an integral part of the Croatian nation, which he wrote about in the first part of his study, entitled "The Origin of Bosnian Muslims." Addressing the topic from the perspective of physical anthropology, he concluded that "the Muslims were

\footnotetext{
30 Aleksander Grabianski, Sinteza povijesti Poljske [The Synthesis of the History of Poland] (Zagreb: Matica hrvatska, 1939), p. 6.

31 Mladen Lorković, Narod i zemlja Hrvata (Zagreb: Matica hrvatska, 1939), pp. 5-7 and 259.

32 Jaroslav Šidak, Crkva Bosanska i problem bogumilstva u Bosni (Zagreb: Matica hrvatska, 1940), pp. 84-85.
} 
the purest Croats in Bosnia". ${ }^{33}$ In addition to various texts on the Macedonian Yürüks, the graves of the Bosnian Kotromanić dynasty, and the Serbian "slava" tradition, Truhelka also dealt with the origin of "the Greek-Eastern confession in Bosnia and Herzegovina." Historically and demographically, he believed that the Ottoman penetration of Europe was crucial to the history of the peoples of South-Eastern Europe after the $15^{\text {th }}$ century. In his research, he tried to prove that the Orthodox population of Bosnia and Herzegovina belonged to the Walachian people of the Balkans, who had "only recently called themselves Serbs" and "with time became the pioneers of Serbhood in Bosnia." Unlike the Muslims and the Catholics, they had the "ije" pronunciation variant and were not an indigenous population, but together invaded Bosnia together with the Turks during the $15^{\text {th }}$ and $16^{\text {th }}$ centuries. They did not belong to the old Bosnian nobility, but lived in hilly and inaccessible areas. In the closing words of this article, Truhelka emphasized that "the offspring of any of these groups cannot derive any rights of indigenousness from the history of the settlement of Bosnia, in opposition to the natives of the Catholic and Islamic faiths. Much less should it be possible for them to claim land where they are merely guests, on behalf of a foreign people to which they only minimally belong, and deny it to the Croats - who are the autochthon population." ${ }^{4}$ These words of Truhelka reflected the Croatian-Serbian conflicts from old Yugoslavia, which erupted precisely in Bosnia and Herzegovina during World War II.

Vatroslav Murvar, a later Croatian political emigrant, published a highly controversial study titled On the Sources of Serbian Falsehoods, in which he discussed the history of the Croatian-Serbian relations in literature, science, and culture. He especially referred to the cultural policy of the failed Karađorđević regime, which had denied the existence of the Croatian language and even the Croatian people as such. Murvar identified the founder of Serbian negationism towards the Croats in the person and work of Vuk Karadžić and his book Srbi svi svuda [All Serbs Everywhere]. In this regard, Murvar pointed out that Karadžić's followers continued along this path when they later set on to "appropriate parts or entire provinces of the Croatian land, distorting historical, numerical, and sociological facts, forging documents, appropriating entire cultural epochs, Croatian literary language, and folk songs, Serbicizing our first literary names, and misrepresenting and belittling all Croatian values, which shows the system of Serbian untruths, persistently presented in a scientific form and called science from the beginning of Serbian literacy to the collapse of the Greater Serbian state." 35

\footnotetext{
33 Ćiro Truhelka, "Podrijetlo bosanskih muslimana", in Studije o podrijetlu - etnološka razmatranja iz Bosne i Hercegovine (Zagreb: Matica hrvatska, 1941), pp. 5-16.

34 Ćiro Truhelka, "O podrijetlu žiteljstva grkoistočne vjeroispovijesti u Bosni i Hercegovini” [On the origin of Orthodox population in Bosnia and Herzegovina], in Studije o podrijetlu etnološka razmatranja iz Bosne i Hercegovine (Zagreb: Matica hrvatska, 1941), pp. 29-43.

${ }_{35}$ Vatroslav Murvar, Na izvorima srpskih neistina (Zagreb: Mala knjižnica Matice hrvatske, 1941), p. 15.
} 
As the whirlwind of war struck Lika and Bosnia and Herzegovina most severely, so did Matica's historiographical editions pay special attention to these Croatian territories. At that time, Bosnian and Herzegovinian topics came into the particular focus of Matica's publications, as the largest armed conflicts of the time were taking place precisely in those areas, which thus became crucial for the survival of the wartime Croatian state. Thus, in 1942, historian Bare Poparić published his Tužna povijest Hercegove zemlje [Sad History of Herceg's Land], in which he wrote about Stjepan Kosača, a ruler of Herzegovina who seceded from Bosnian royal power, considering him responsible for the fall of Herzegovina under the Ottoman rule in 1482. In his introduction, Poparić drew his reader's attention to the fact that "Herzegovina has returned to its old and natural state frame after a full millennium, and so this will encourage everyone all the more to ponder on these memories, which teach us quite manifestly how a branch torn from its trunk can and must die." Therefore, he expressed his wish that "the former Herzegovinian land should within the Independent State of Croatia regain the happiness it used to enjoy in King Tomislav's time." ${ }^{36}$

Another historian, Rudolf Horvat, wrote historical sketches about Lika and Krbava. ${ }^{37}$ Augustin Kristić wrote about the medieval history of the Bosnian town of Kreševo, which he regarded as one of the centuries-old centres of Bosnian Catholicism, in which there had never been a significant historical presence of either Muslims or Orthodox. According to Kristićs conclusions, its population had a Croatian character from the earliest medieval times, regardless of whether Catholic or Muslim by faith, so those Serbian historians who claimed that Bosnia was a Serbian country and by the same token argued that there had never been any Croats there, were wrong. Related to this, regarding the population of the Kreševo area, such Serbian historians wanted to "create the historical fact that most of the people in this area are descendants of Croatized Saxons." 38

In 1943, Matica republished Radoslav Lopašićs Bihać i bihaćka krajina [Bihać and the Bihać Region], originally published in 1890. Lopašićs foreword was especially suited to the Ustasha regime, as he had written back then that "the religious enthusiasm of our Muslim brothers should combine with a noble and sincere feeling for our fatherland, kin, and mother tongue, and the difference in religion should never bother us again, as that is most to blame for our common

\footnotetext{
36 Bare Poparić, Tužna povijest Hercegove zemlje (1437.-1482.) (Zagreb: Matica hrvatska, 1942), p. 8 .

37 Rudolf Horvat, Lika i Krbava: povijesne crtice, bilješke i slike [Lika and Krbava: Historical sketches, notes, and pictures] (Zagreb: Matica hrvatska, 1941).

38 Augustin Kristić, Kreševo: obrtni, građanski i narodni život [Kreševo: Its economic, civic, and public life] (Zagreb: Matica hrvatska, 1941), pp. 7-9 and 13.
} 
affliction." ${ }^{39}$ In 1944, the intendant of the Croatian National Theatre in Sarajevo, Ahmed Muradbegović (1898-1972), printed with Matica his historical study on Omer-pasha Latas, a Sultan's man and a reformer from the last phase of Ottoman Bosnia, and his conflicts with the Bosnian-Herzegovinian Bey. ${ }^{40}$

The turning point of the war in 1943, after the Tehran conference and the adoption of the Partisan Declaration in Jajce, when the possibility of a new Yugoslavia was increasingly foreseeable, Matica, under its editor and translator Fedor Pucek, published a study by Ivo Pilar from 1918 titled Južnoslavensko pitanje [The South Slav Question]. Pilar's work, originally written in German, was intended to serve as a scientifically substantiated argument against such a solution in the southeast of Europe. Its translator Pucek indicated that Pilar's 1918 study of the Yugoslav question was still a topical issue, as "Südland's work that Matica Hrvatska is now presenting to the Croatian public, as much as 25 years after the German edition, and at a time when more has happened in these 25 years than otherwise in a hundred, and when we are in the midst of political and social turmoil and transformation, unmatched by any in many centuries behind us, it still welcome, since it has not lost much of its modernity." ${ }^{41}$

\section{Historiographical editions 1945-1989}

The collapse of the Croatian state in 1945 brought Matica Hrvatska and its publishing activity, at least when it comes to historiographical editions, into a period of intellectual and cultural decline. Many of its members were scattered around the world as political refugees, and a considerable number of them were directly liquidated by the new, Communist-governed Yugoslav regime. Until as late as the 1960s, Matica's historiographical publications were not even a shadow of the past ones, either in quality or in quantity. Publication of works on Croatian history was particularly suppressed, but even regional history did not fare much better compared to the previous periods. An exception was a history of Split by Grga Novak, printed in three volumes in the Split branch of Matica Hrvatska (1957, 1961, and 1965), covering the history of Split from the prehistoric times to the Croatian national revival in Dalmatia, or until the National Party's conquest of the Split municipality in $1882 .{ }^{42}$

\footnotetext{
39 Radoslav Lopašić, Bihać i bihaćka krajina: mjestopisne i poviestne crtice [Bihać and the Bihać region: Geographical and historical sketches] (Zagreb: Matica hrvatska, 1943), p. 7.

40 Ahmed Muradbegović, Omer-paša Latas u Bosni [Omer-pasha Latas in Bosnia] (Zagreb: Matica Hrvatska, 1944), p. 7.

41 Fedor Pucek, "Predgovor prevodioca” [Translator's foreword], in Südland Južnoslavensko pitanje (repr. Varaždin: Hrvatska demokratska stranka, podružnica Varaždin, 1990, 1st ed. 1943), p. XXIX.

42 Grga Novak, Povijest Splita: od 1797. do 1882, [The history of Split: From 1797 to 1882], vol. 3 (Split: Ogranak Matice hrvatske u Splitu, 1965), p. 360.
} 
Central to the period before the Croatian Spring was the Pregled historije narodnoslobodilačke borbe Jugoslavije [Overview of the History of the People's Liberation Struggle in Yugoslavia] by Tomo Cubelić, teacher at the military-political school, and Milovan Milostić, a JNA major. These were two unknown authors who obviously had no careers as historians during previous Yugoslavia or NDH, and whose book was nevertheless published in nothing less than nine editions from 1952 to 1960. Dalmatian partisan and writer Vjekoslav Kaleb helped them with this endeavour as an editor. Both writers emphasized in their opening remarks that the purpose of their work was to prove the leading role of the Yugoslav Communist Party in the war and the revolution that created "the foundations for a new social order in our country - Yugoslavia." ${ }^{43}$ It was in the same spirit of needing to build up a revolutionary partisan tradition that Rodoljub Čolaković, a Bosnian Serb, partisan, and Communist, a former Zagreb student, wrote his memories from World War II, published in several editions between 1947 and 1956 under the title Zapisi iz oslobodilačkoga rata [Notes from the Liberation War]. As for the classics, Thucydides' Povijest peloponeskoga rata [History of the Peloponnesian War] was published in 1957, while other works, such as Mijo Mirkovićs Seljaci u kapitalizmu: agrarno-ekonomske studije [Peasants in Capitalism: Agrarian and Economic Studies] from 1952, Stjepan Antoljak's Bune pučana i seljaka [People's and Peasants' Revolts] from 1956, and Vaso Bogdanov's Hrvatska ljevica u godinama revolucije 1848.-49. u svjetlu naše četredesetosmaške štampe [The Croatian Left in the Years of the Revolution 1848-49 in the Light of Our 1848 Press] from 1949, were if not openly Marxist, then certainly pro-Marxist in their approach to the study of history.

Antoljak thus placed the socio-economic structures in the focus of his discussion, with an emphasis on the social uprisings of peasants and serfs in the past of the Croatian lands. ${ }^{44}$ Bogdanov attempted a new interpretation of 1848 , which was fundamentally different from the writing of Croatian bourgeois historiography in the pre-Communist era. Concerning this, he wrote in his preface that there had been a "Croatian Left in 1848," which did not sympathize with the reactionary forces in Croatia and the entire Monarchy, but that its appearance had been intentionally ignored in the official history of bourgeois provenance. Therefore, Bogdanov emphasized that "what was the most important, most significant, and at the same time the most positive thing in the history of the Croatian movement of 1848, namely the struggle of the Croatian people against the domestic reaction of Jelačić and the Austrian counter-revolution, the decisive commitment of our masses on the side of the Italian, Hungarian, and European revolution - that has hitherto remained completely unknown." ${ }^{45}$

\footnotetext{
43 Tomo Čubelić and Milovan Milostić, Pregled historije Narodnooslobodilačke borbe Jugoslavije (Zagreb: Matica hrvatska, 1952), p. 5.

44 Stjepan Antoljak, Bune pučana i seljaka (Zagreb: Matica hrvatska, 1956), pp. 10-11.

45 Vaso Bogdanov, Hrvatska ljevica u godinama revolucije 1848-49. u svjetlu naše četrdesetosmaške štampe. (Zagreb: Matica hrvatska, 1949), p. 5.
} 
One of the most significant works published during this period was the history of Matica Hrvatska itself, published in 1963 by its then president, Jakša Ravlić, on the occasion of the $120^{\text {th }}$ anniversary of its foundation. Ravlić tried to reconcile Matica's history, which was, in general, a product of conservative and national dynamism, with the "fraternity and unity" of the socialist society. ${ }^{46}$ Of the approximately 250 pages of the main text, Ravlić devoted only 35 pages to the period from 1918 to 1945 , which indicates that he was not really guided by impartial motives in an effort to give an objective account of Matica's history. Even the more so as Matica Hrvatska, after its exceptionally fruitful activity during the second half of the $19^{\text {th }}$ century, had experienced yet another upswing and exerted strong public influence on the Croatian public and cultural life during that period, especially during the presidency of Filip Lukas (1928-1945) and especially in its publishing activity, and it seems that this period would have deserved a more extensive treatment. Accordingly, Ravlićs final assessment, which was of course determined by his ideological starting points, was rather negative concerning Matica's activities during that period. In his closing remarks, Ravlić noted that after 1945 and the war victory of the Yugoslav partisans, Matica showed itself as "ideologically incompatible with what the Croats and other peoples of Yugoslavia have fought for." ${ }^{37}$

In the early 1960s, the national issue was discussed for the first time after the war in the highest political and intellectual circles of Tito's regime. Thus, in 1961, Dobrica Ćosić and Dušan Pirjevec discussed the internal constellations of power in Yugoslavia from the opposing positions, and in 1962 Tito mentioned "nationalism" for the first time as a threat to maintaining a unified Yugoslav party and state. In Croatia, in response to these movements at the top level, the $130^{\text {th }}$ anniversary of the Croatian National Revival was used to initiate the "Croatian Spring." After his 1963 history of Matica, Ravlić edited Kačićs Razgovori ugodni naroda slovinskoga [Pleasant Conversations of the Slavic People] in 1967, the year of the Declaration on the Name and Position of the Croatian Language, showing renewed interest in Croatian folk and cultural tradition. Ravlić emphasized the eternal topicality of Kačićs book, saying that "although the epic time here and around us has ceased, it lives a full-blooded life from its inception to this day", because "there is something more lively, something stronger, something more lasting in his literary works, especially in the Pleasant Conversations of the Slavic People." Among these eternal ideals promoted by Kačić, Ravlić particularly pointed out love for freedom, struggle for justice, and defence of one's home, which made Kačić undoubtedly "the most powerful Croatian enlightenment writer and educator for the purpose of self-preservation." 48

\footnotetext{
$\overline{46}$ Jakša Ravlić, Matica hrvatska 1842.-1962. (Zagreb: Matica hrvatska, 1963), p. 1.

47 Ibid., p. 198.

48 Jakša Ravlić, "Predgovor" [Foreword], in: Andrija Kačić Miošić, Razgovor ugodni naroda slovinskoga, Pet stoljeća hrvatske književnosti, vol. 21 (Zagreb: Matica hrvatska, 1967), p. 21.
} 
In 1968, Ivan Kujundžić published his Izvori za povijest bunjevačko-šokačkih Hrvata [Sources for the History of the Bunjevac-Šokac Croats] and Zvonimir Kulundžić his Miškina: presjek kroz stvarnost hrvatskog sela od Khuen Hedervarya do poglavnika [Miškina: A Cross-section through the Reality of a Croatian Village from Khuen-Héderváry to Poglavnik], published by Matica's branches in Koprivnica and Ogulin. Among the greatest publishing events of the "Croatian Spring" one should note five volumes of Klaić's Povijest Hrvata [History of the Croats] from 1972, Starčević's texts and speeches, for which the former editor-in-chief of Hrvatska revija, Blaž Jurišić, wrote a foreword, and Tuđman's 1969 study Velike ideje i mali narodi [Great Ideas and Small Peoples]. Tuđman here dealt with the way in which major powers abused great ideas such as "Slavic reciprocity" and "socialist internationalism", presenting his own "philosophy of history," distinguished by "eternal struggles and shifts of old and new social systems and ideas, in lasting oppositions between the pursuit of hegemony by the great and the self-preservation of small peoples, in the never-ending contradiction between the overarching principles of the great ideas and their hypocritical abuse by the great powers with regard to the living welfare of small peoples." 49 Because of the high demand for the book, it saw another, expanded edition in 1970, published by Matica's branch in Zadar, which eventually turned Tuđman into a communist dissident. That is also why he received the jubilee award of the emigrant Hrvatska revija for his work.

An important publication with several historical articles was the first volume of Hrvatski znanstveni zbornik from 1971. Among the contributors, there were Tuđman with his "Slom vidovdanskog parlamentarnog centralizma i državno-politička kriza Kraljevine SHS“ ["Breakdown of the Vidovdan Parliamentary Centralism and the State-Political Crisis of the Kingdom of SHS”], Miroslav Brandt with "Dualistička zamisao o otkupu đavoljeg prava na čovjeka u novozavjetnim tekstovima i patristici" ["The Dualist Concept of the Redemption of the Devil's Right to Man in the New Testament and in Patristics"], Jozo Ivičević with his "Odrednice unitarističkog nacionalnog programa I. i II. kongresa KPJ" ["Determinants of the Unitarian National Programme at the $1^{\text {st }}$ and $2^{\text {nd }}$ Congress of KPJ"], and Mihajlo Ogrizović with an article on "Marija Jambrišak - borac za prava i odgoj žene (1847-1937)“ [“Marija Jambrišak - A Fighter for Women's Rights and Education (1847-1937)”]. In the concluding part of his article, Tuđman emphasized that King Alexander's policy sought from the outset to introduce an "autocratic-absolutist rule," which was then installed immediately after January 6, 1929. ${ }^{50}$ The dictatorship was introduced in order to maintain the Greater Serbian centralism established in the Vidovdan Constitution, since the very existence of weakened parliamentarism threat-

\footnotetext{
$\overline{49} \quad$ Franjo Tuđman, Velike ideje i mali narodi (Zagreb: Matica hrvatska, 1969), p. 7.

50 Franjo Tuđman, "Slom vidovdanskog parlamentarnog centralizma i državno-politička kriza Kraljevine SHS," Hrvatski znanstveni zbornik, vol. 2 (Zagreb: Matica hrvatska 1971), p. 106.
} 
ened such policy of Belgrade. Ivičević, on the other hand, wrote about the interwar Communist movement and its views on the national issue between the founding of the Yugoslav party until the outbreak of World War II. His final judgment called for taking into account the period after the war. Specifically, he argued that the Yugoslav Communist movement reaffirmed, according to the Soviet model, the interwar party unitarism and centralism after the victory of the socialist revolution. However, after the conflict with Stalin in 1948, Yugoslavia definitely turned towards establishing a "national pluralist regime," arm in arm with the "self-managing pluralist principle at all levels and in all structures of the Yugoslav socialist community." 51

As a member of Matica Hrvatska and a university professor, Miroslav Brandt contributed with an article on the medieval heresy of "neo-Manichaean dualism." He set out to develop his argument with the notion that, despite the ecclesiastical condemnation of dualist beliefs at the councils in Nicaea and Constantinople during the $4^{\text {th }}$ century, many New Testament texts as well as the patristic tradition actually adopted such beliefs in certain places. ${ }^{52}$ Mihajlo Ogrizović focused on the role of teacher Marija Jambrišak (1847-1937), who in the second half of the $19^{\text {th }}$ and the beginning of the $20^{\text {th }}$ century advocated the education of women and their inclusion in the public life of what was then Croatia. He pointed out that she was "one of the more prominent women in Croatia at the time, who, through her sacrificing and selfless work, among other things, contributed greatly to establishing the foundations for women's education and training of educators and teachers." ${ }^{53}$

In the second volume of the same series, which came out in 1971, authors participating with historical topics included Vladimir Košćak, Mate Zorić, and Ivan Pederin. Admittedly, Zorić and Pederin wrote on the history of Croatian literature with titles such as "Hrvatska i Hrvati u talijanskoj lijepoj književnosti" ["Croatia and the Croats in Italian Belles-lettres"] and "Životinje i cvijeće kao stilska sredstva hrvatskih začinjavaca" ["Animals and Flowers as Stylistic Figures in Early Croatian Anonymous Authors"], which also reflected the spirit of the Croatian Spring and its struggle to restore the national spirit. Košćak addressed the earliest days or the formative phase of Stjepan Radić, his growing up and education, in an article titled "Mladost Stjepana Radića" ["Stjepan Radić's Youth"]. However, despite the fact that the article itself was related to national history, Košćak used Radić's year of birth (1871) to position his topic within the revolutionary tradition by highlighting the historical importance of

\footnotetext{
51 Jozo Ivičević, “O drednice unitarističkog nacionalnog programa I. i II. kongresa KPJ,” Hrvatski znanstveni zbornik, vol.1 (Zagreb: Matica hrvatska, 1971), p. 172.

52 Miroslav Brandt, "Dualistička zamisao o otkupu đavoljeg prava na čovjeka u novozavjetnim tekstovima i patristici," Hrvatski znanstveni zbornik, vol. 1 (Zagreb: Matica hrvatska, 1971), p. 191.

53 Mihajlo Ogrizović, "Marija Jambrišak - borac za odgoj i prava žene: uz 100. obljetnicu Hrvatskog predagoškog književnog zbora," Hrvatski znanstveni zbornik, vol. 1 (Zagreb: Matica hrvatska, 1971), p. 231.
}

182 
the Paris Commune for the future history of the workers' revolutionary movement in European politics. ${ }^{54}$ In 1969, Matica published a volume on the Croatian National Revival in Dalmatia and Istria during the $19^{\text {th }}$ century. In his presentation of the volume, Nikša Stančić pointed out that it was the proceedings of a scholarly convention that had taken place in Pula and Zadar in 1962 to celebrate the $100^{\text {th }}$ anniversary of the publication of Narodni list in Zadar. Sixteen authors contributed to the volume from different fields, such as history, literary history, or art history (D. Foretić, B. Milanović, Ž. Črnja, G. Novak, D. Šepić, T. Peruško, V. Zidarić, R. F. Barbalić, V. Vitolović, V. Bratulić, K. Prijatelj, M. Mirković, J. Ravlić, J. Beroš, V. Maštrović, and J. Grabovac), with texts on the revival movements in Istria and Dalmatia during the second half of the $19^{\text {th }}$ century. ${ }^{55}$ The lecture on the Illyrian national revival by the leading literary author of the epoch, Miroslav Krleža, given in Zagreb in 1966, for its $130^{\text {th }}$ anniversary, and this historical interest in the national revivals in the Croatian lands, showed the increased attention paid to national history by the scholarly and cultural public in the general atmosphere of the "Croatian Spring."

After the collapse of the Croatian Spring in 1971, when Matica Hrvatska was banned and its leadership and members persecuted, its publishing activity continued within Matica Hrvatska's Publishing House. By 1989, it had printed Klaićs Povijest Hrvata [History of the Croats] four times: in 1980, 1981, 1985, and 1988. The only important historiographical works in the great scarcity of this period, the time of "Croatian silence," was - apart from Klaić's book - Vinko Foretićs Povijest Dubrovnika do 1808. godine [History of Dubrovnik before 1808] and Trpimir Macan's study on the Dalmatian national revivalist Miha Klaić, both published in 1980. Foretićs book was a synthesis of Dubrovnik's history of Dubrovnik before 1808 in two parts, the first one focusing on the early days of its foundation to 1526, and the second part on the period from 1526 until the fall of the Dubrovnik Republic and the French rule. In his foreword, Foretić emphasized that his history of Dubrovnik was a synthesis that "mainly contains the history of political life in the city and the Republic, based on economic power and dependent on its oscillations, development, flourishing, stagnation, and decline." 56 Macan, on the other hand, encouraged by Prof Jaroslav Šidak from the Faculty of Arts and Social Sciences, ventured a biography of Miho Klaić (1829-1896), champion of the Croatian National Revival in Dalmatia, which was a somewhat later reflection of the increased interest in Croatian history that was characteristic of the Croatian Spring. ${ }^{57}$

\footnotetext{
54 Vladimir Košćak, "Mladost Stjepana Radića”, Hrvatski znanstveni zbornik, vol. 2 (Zagreb: Matica hrvatska, 1971), pp. 123-124.

55 Nikša Stančić, “Zbornik Hrvatski narodni preporod u Dalmaciji i Istri”, Časopis za suvremenu povijest 2 (1971): 253-256.

56 Vinko Foretić, Povijest Dubrovnika do 1808. godine, part 1 (Zagreb: Nakladni zavod Matice hrvatske, 1980), p. 14.

57 Trpimir Macan, Miho Klaić (Zagreb: Nakladni zavod Matice hrvatske, 1980), p. 6.
} 


\section{Historiographical editions after 1989}

The fall of the Berlin Wall and a partial liberalization of the Yugoslav society that occurred in the period 1989-1990, which led to the renewal of Matica's activity, resulted in new publications on historical topics, with a particular upswing after 1990. In 1989, Tuđman made his reappearance with a book that would later be translated into English as Horrors of War: Historical Reality and Philosophy, in which he refuted one of the founding myths of Tito's Yugoslavia, the one about the genocidal inclination of the Croatian people. Tudman estimated that the entire Yugoslav historiography in the last phase of socialism was dominated by the "re-examination of old contributions and the presentation of new ones, which instead of being researched and objectively scrutinized, are being judged from a biased standpoint." ${ }^{38}$ That same year, the Split-based lawyer and historian Ivan Mužić appeared with the fourth edition of his history of Croatian and Yugoslav Freemasonry, and his second book with a hypothesis on the crucial participation of an indigenous constituent in Croatian ethnogenesis, by which he weakened to some extent the generally accepted Slavic hypothesis on the origin of Croats at the end of the second Yugoslavia. Mužićs research on Croatian Freemasonry led him to conclude that, unlike other national Freemasonries, it was often antipatriotic, and as such often placed itself in the service of foreign interests. In addition, according to his observations, during the interwar period Yugoslav Freemasonry wanted to "physically destroy Catholicism in Yugoslavia," which is why he considered it most responsible for the failure of the Concordat of 1937, which was finally to regulate the relations between the Church and the Yugoslav state..$^{59}$ In his second study on the ethnogenesis of Croats from 1989, Mužić developed his idea on the importance of the often-neglected indigenous presence, as noted in the foreword by the historian and archaeologist Mate Suić. ${ }^{60}$

After the democratic elections of 1990, new editions of books published before 1945 appeared, as well as books written during the previous decades in Croatian political emigration. The former group included Antun Dabinovićs Hrvatska državna i pravna povijest [Croatian Political and Legal History] from 1940 and Josip Horvat's biography of Ante Starčević from the same year, both republished in 1990. In the new edition of Dabinovićs work, the publisher emphasized that "Matica Hrvatska’s Publishing House has decided to republish this precious book so that the modern generations may become acquainted with the

\footnotetext{
58 Franjo Tuđman, Horrors of War: Historical Reality and Philosophy, trans. Katarina Mijatović (New York: M. Evans \& Co., 1996), p. 11. The English edition is a revised edition of his Bespuća povijesne zbiljnosti: rasprava o povijesti i filozofiji zlosilja (Zagreb: Nakladni zavod Matice hrvatske, 1989).

59 Ivan Mužić, Masonstvo u Hrvata [Freemasonry among the Croats] (Zagreb: Nakladni zavod Matice hrvatske, 1989), p. 13.

60 Ivan Mužić, Podrijetlo Hrvata [The origin of the Croats] (Zagreb: Nakladni zavod Matice hrvatske, 1989), p. 7.
} 
older part of Croatian political and legal history," which had been undesirable during the dictatorship of the Yugoslav Communists. ${ }^{61}$ After Tuđman's victory in the 1990 presidential elections, his book Horrors of War was reprinted and his book Nationalism in Contemporary Europe, published in 1981 at the Columbia University in New York, first appeared in a Croatian edition, and would have a total of five issues by 1996. Tuđman here interpreted the strength and vitality of nationalisms in Eastern Europe during the second half of the $20^{\text {th }}$ century as a response of Eastern European peoples to the imposition of Communist internationalism. ${ }^{62}$ In 1990, Matica Hrvatska's Publishing House also published the book Hrvati i Srbi - dva stara različita naroda [Croats and Serbs - Two Ancient Different Peoples] by Dominik Mandić, printed in emigration in 1971. The foreword to the Croatian edition was Neven Budak, historian from the Faculty of Arts and Social Sciences, who pointed out that after a political anathema, Mandić was now returning to Croatian history and culture. In his assessment of Mandićs work, Budak eventually asked whether it was possible to declare Mandić as "the founding father of Croatian-Serbian comparative history." ${ }^{63}$

Two years later, in 1992, Kljakovićs memoirs titled U suvremenom kaosu [In Modern Chaos], originally published in Buenos Aires in 1952, first appeared in a Croatian edition. In his editorial note, Stjepan Šešelj emphasized that Kljakovićs person and work had been condemned to oblivion during Yugoslav communism. Therefore, he wrote in 1992 that "to this day, Jozo Kljaković has not been honoured with an art monograph, and none of the many streets in $\mathrm{Za}$ greb bears his name." 64 Therefore, the Croatian edition of his emigrant book was to indicate his return to the public and cultural life of his homeland. In 1992, Stjepan Antoljak published an extremely valuable study on the history of Croatian historiography before 1918, in two volumes. In his preface to the first book, Antoljak stated that anyone who wanted to deal with Croatian history had to know the development of Croatian historical science. ${ }^{65}$ Matica also posthumously published a manuscript by Franjo Buntak, a historian involved with the history of Zagreb: around 1000-page long History of Zagreb, eleven years after his death. ${ }^{66}$ That same year, in 1996, Tuđman's book Big Ideas and Small Peoples appeared in the fifth, enlarged edition. The foreword was written by Andelko Mijatović, who pointed out that even after the fall of the Communist regimes,

\footnotetext{
61 Antun Dabinović, Hrvatska državna i pravna povijest (2nd ed. Zagreb: Nakladni zavod Matice hrvatske, 1990), p. 1.

62 Franjo Tuđman, Nacionalno pitanje u suvremenoj Europi (Zagreb: Nakladni zavod Matice hrvatske, 1990), p. 9.

63 Dominik Mandić, Hrvati i Srbi - dva stara različita naroda (Zagreb: Nakladni zavod Matice hrvatske, 1990), p. 13.

64 Jozo Kljaković, U suvremenom kaosu (Zagreb: Matica hrvatska, 1992), 388.

65 Stjepan Antoljak, Povijest hrvatske historiografije do 1918., vol 1 (Zagreb: Nakladni zavod Matice hrvatske, 1992), p. 5.

66 Franjo Buntak, Povijest Zagreba (Zagreb: Nakladni zavod Matice hrvatske, 1996), p. 6.
} 
Tuđman's preoccupation with the relations between large and small peoples remained topical. ${ }^{67}$ In the same year, Trpimir Macan published the memoirs of journalist and publicist Tias Mortigia. Mortigia was imprisoned and sentenced to death by the Yugoslav authorities in 1947, after being extradited by the English police from Rome. ${ }^{68}$

\section{Conclusion}

This article focuses on the historiographical editions published by Matica Hrvatska's Publishing House from 1918 to the first half of the 1990s, which influenced the formation of Croatian spiritual and cultural identity over a period of almost one century. These editions have been chronologically divided into three significant periods of their publication by Matica, which coincide with important historical and political periods: the first from the collapse of the Austro-Hungarian Monarchy and the entry of the Croatian people into the first Yugoslav state in 1918 until the collapse of the Independent State of Croatia in 1945; the second from the establishment to the fall of the second Yugoslavia, from 1945 to 1989; and the third after the democratic changes in 1990 and the creation of the Croatian state. It has been shown that the books published by Matica Hrvatska strongly reflected the political aspirations of each epoch, while the political and social changes largely influenced the publishing policy of this oldest Croatian cultural institution. Its publishing activity particularly flourished during the presidency of Filip Lukas, between 1928 and 1945, which was certainly one of the most productive periods in Matica's history.

Unlike the socialist period, when national themes were repressed and ignored in a certain way, and there were almost no treatments of local history, in the said period Matica not only dealt with national history, but also printed numerous editions dealing with the local histories of specific Croatian towns and regions. Matica experienced its greatest crisis after World War II, when its publishing activities were suppressed, primarily because of its previous role in promoting Croatian nationalism and the fact that its membership had given strong support to the establishment of the Independent State of Croatia in 1941, which in no way fitted the overall cultural policy of the post-war Communist regime. The culmination was the final ban of Matica Hrvatska in 1972, because of its significant role in the Croatian Spring during the 1960s, until the removal of the Croatian Communist leadership in Karađorđevo in 1971.

\footnotetext{
67 Anđelko Mijatović, "Predgovor" [Foreword], in: Franjo Tuđman, Velike ideje i mali narodi (Zagreb: Nakladni zavod Matice hrvatske, 1996), p. 2.

68 Tias Mortigia, Moj životopis [My life] (Zagreb: Nakladni zavod Matice hrvatske, 1996).
} 
But despite of such moves by the regime, Matica's publishing work managed to survive in Matica Hrvatska's Publishing House. This institute had particularly extensive publishing activity in the years when the Yugoslav Communist system began to disintegrate, in 1989-1990, when it published the work of a former dissident and the future Croatian President, Franjo Tuđman. In the aftermath of establishing a democratic Croatian state, Matica renewed its activities towards the end of the century, including publishing, and reprinted books on topics from national and local history or published the previously banned emigration books in their first Croatian editions.

\section{Bibliography}

Antoljak, Stjepan. Bune pučana i seljaka. Zagreb: Matica hrvatska, 1956.

Antoljak, Stjepan. Povijest hrvatske historiografije do 1918., vol. 1. Zagreb: Nakladni zavod Matice hrvatske, 1992.

Bjelovučić, Niko. Crvena Hrvatska i Dubrovnik. Zagreb: Matica hrvatska, 1929.

Bogdanov, Vaso. Hrvatska ljevica u godinama revolucije 1848-49. u svjetlu naše četrdesetosmaške štampe. Zagreb: Matica hrvatska, 1949.

Brandt, Miroslav. "Dualistička zamisao o otkupu đavoljeg prava na čovjeka u novozavjetnim tekstovima i patristici." In: Hrvatski znanstveni zbornik, vol. 1. Zagreb: Matica hrvatska, 1971.

Buntak, Franjo. Povijest Zagreba. Zagreb: Nakladni Zavod Matice hrvatske, 1996.

Cihlar Nehajev, Milutin. O stogodišnjici hrvatskog narodnog preporoda (1830.-1930.). Zagreb: Mala knjižnica Matice hrvatske, 1931.

Čubelić, Tomo and Milovan Milostić. Pregled historije Narodnooslobodilačke borbe Jugoslavije. Zagreb: Matica hrvatska, 1952.

Dabinović, Antun. Hrvatska državna i pravna povijest, $2^{\text {nd }}$ ed. Zagreb: Nakladni zavod Matice hrvatske, 1990.

Foretić, Vinko. Povijest Dubrovnika do 1808. godine, part 1. Zagreb: Nakladni zavod Matice hrvatske, 1980.

Grabianski, Alexander. Sinteza povijesti Poljske. Zagreb: Matica hrvatska, 1939.

Horvat, Josip. Tisuću osamsto četrdeset osma. Zagreb: Matica hrvatska, 1934.

Horvat, Rudolf. Hrvatska podravina, povijesne rasprave, crtice i bilješke. Zagreb: Matica hrvatska, 1933. 
Horvat, Rudolf. Lika i Krbava: povjesne crtice, bilješke i slike. Zagreb: Matica hrvatska, 1941.

Ivičević, Jozo. “Odrednice unitarističkog nacionalnog programa I. i II. kongresa KPJ.” In: Hrvatski zanstveni zbornik, vol. 1. Zagreb: Matica hrvatska, 1971.

Katić, Lovre. Pregled povijesti Hrvata. Zagreb: Matica hrvatska, 1938.

Klaić, Vjekoslav. "Hrvatski sabori do godine 1790. In: Zbornik Matice hrvatske o tisućoj godišnjici Hrvatskog kraljevstva. Zagreb: Matica hrvatska, 1925.

Kljaković, Jozo. U suvremenom kaosu. Zagreb: Matica hrvatska, 1992.

Košćak, Vladimir. "Mladost Stjepana Radića." In: Hrvatski znanstveni zbornik, vol. 2, 123-165. Zagreb: Matica Hrvatska, 1971.

Kristić, Augustin. Kreševo: obrtni, građanski i narodni život. Zagreb: Matica hrvatska, 1941).

Laszowski, Emil. Gorski kotar i Vinodol. Zagreb: Matica hrvatska, 1923.

Lopašić, Radoslav. Bihać i bihaćka krajina: mjestopisne i poviestne crtice. Zagreb: Matica hrvatska, 1943.

Lozovina, Vinko. Niccolo Macchiavelli i njegovo politička nauka. Zagreb: Matica hrvatska, 1928. 1936. . Dalmacija u hrvatskoj književnosti. Zagreb: Matica hrvatska,

Lukas, Filip. Strossmayer i hrvatstvo. Zagreb: Matica Hrvatska, 1925.

(ed.). Zbornik Matice hrvatske. Hrvatskom narodu, njegovim prošlim naraštajima na spomen, sadašnjima i budućima na pobudu o tisućoj godišnjici hrvatskoga kraljevstva. Zagreb: Matica hrvatska, 1925.

. "Predgovor”. In: Safvet beg Bašagić, Znameniti Hrvati Bošnjaci i Hercegovci u turskoj carevini. Zagreb: Matica hrvatska, 1932.

. "Starčević". In: Zbornik Dr. Ante Starčević o 40. obljetnici smrti. Zagreb: Matica hrvatska, 1936.

. Problem hrvatske kulture. Zagreb: Matica hrvatska, 1938.

Lorković, Mladen. Narod i zemlja Hrvata. Zagreb: Matica hrvatska, 1939.

Macan, Trpimir. Miho Klaić. Zagreb: Nakladni zavod Matice hrvatske, 1980.

Mandić, Dominik. Hrvati i Srbi dva stara različita naroda. Zagreb: Nakladni zavod Matice hrvatske, 1990.

Manojlović, Gavrilo. Povijest starog Orijenta do XI. stoljeća, vol. 1. Zagreb: Matica hrvatska, 1923.

Mijatović, Anđelko. "Predgovor”. In: Franjo Tudman, Velike ideje i mali narodi. Zagreb: Nakladni zavod Matice hrvatske, 1996.

Mažuran, Ive and Josip Bratulić. Spomenica Matica hrvatska 1842.-2002. Zagreb: Matica Hrvatska, 2004. 
Muradbegović, Ahmed. Omer-paša Latas u Bosni. Zagreb: Matica Hrvatska, 1944.

Mortigia, Tias. Moj životopis. Zagreb: Nakladni zavod Matice hrvatske, 1996.

Murvar, Vatroslav. $\mathrm{Na}$ izvorima srpskih neistina. Zagreb: Mala knjižnica Matice hrvatske, 1941.

Mužić, Ivan. Masonstvo u Hrvata. Zagreb: Nakladni zavod Matice Hrvatske, 1989.

1989.

Podrijetlo Hrvata. Zagreb: Nakladni zavod Matice hrvatske,

Nagy, Josip. “Predgovor”. In: Vjekoslav Klaić, Ime Hrvat i Hrvatska. Zagreb: Matica hrvatska, 1930.

Novak, Grga. Povijest Splita: od 1797. do 1882., vol. 3. Split: Ogranak Matice hrvatske u Splitu, 1965.

Ogrizović, Mihajlo. "Marija Jambrišak - borac za odgoj i prava žene: uz 100.obljetnicu Hrvatskog predagoškog književnog zbora.” In: Hrvatski zanstveni zbornik, vol. 1. Zagreb: Matica hrvatska, 1971.

Radica, Bogdan. Živjeti nedoživjeti - uspomene hrvatskog intelektualca kroz moralnu i ideološku krizu zapada, vol. 1. Munich and Barcelona: Hrvatska revija, 1982.

Pekić, Petar. Povijest Hrvata u Vojvodini: od najstarijih vremena do 1929. godine. Zagreb: Matica hrvatska, 1930.

Poparić, Bare. Pregled povijesti pomorstva. Zagreb: Matica hrvatska, 1932. hrvatska, 1942). . Tužna povijest Hercegove zemlje (1437.-1482.). Zagreb: Matica

Pucek, Fedor. "Predgovor prevodioca." In: Südland, Južnoslavensko pitanje ( $1^{\text {st }}$ ed. 1943). Varaždin: Hrvatska demokratska stranka, podružnica Varaždin, 1990.

Ravlić, Jakša. Matica hrvatska 1842.-1962. Zagreb: Matica hrvatska, 1963. . "Predgovor". In: Andrija Kačić Miošić, Razgovori ugodna naroda slovinskoga. Pet stoljeća hrvatske književnosti 21. Zagreb: Matica hrvatska, 1967.

Stančić, Nikša. "Zbornik Hrvatski narodni preporod u Dalmaciji i Istri," Časopis za suvremenu povijest 2 (1971): 253-256.

Starčević, Mile. Dr. Ante Starčević i Srbi. Zagreb: Matica hrvatska, 1936.

Szabo, Gjuro. Sredovječni gradovi Hrvatske i Slavonije. Zagreb: Izvanredno izdanje Matice Hrvatske, 1920.

Šegvić, Kerubin. Toma Archiđakon i njegovo djelo. Zagreb: Matica hrvatska, 1927. 
ka, 1930.

. Luka Botić: njegov život i njegovo djelo. Zagreb: Matica hrvats-

Šidak, Jaroslav. Crkva Bosanska i problem bogumilstva u Bosni. Zagreb: Matica hrvatska, 1940.

Šišić, Ferdo. Dokumenti o postanku Kraljevine Srba, Hrvata i Slovenaca, 1914.-1919. Zagreb: Matica Hrvatska, 1920. ca hrvatska, 1920.

. Jadransko pitanje na Konferenciji mira u Parizu. Zagreb: Mati. Kako je došlo do okupacije a onda do aneksije Bosne i Hercegovine (1878. odnosno 1908.). Zagreb: Matica hrvatska, 1938.

Truhelka, Ćiro. "Podrijetlo bosanskih muslimana." In: Studije o podrijetlu - etnološka razmatranja iz Bosne i Hercegovine. Zagreb: Matica hrvatska, 1941. . "O podrijetlu žiteljstva grkoistočne vjeroispovijesti u Bosni i Hercegovini.” In: Studije o podrijetlu - etnološka razmatranja iz Bosne i Hercegovine. Zagreb: Matica hrvatska, 1941.

Tuđman, Franjo. Velike ideje i mali narodi. Zagreb: Matica hrvatska, 1969. . "Slom vidovdanskog parlamentarnog centralizma i državno-politička kriza Kraljevine SHS.” In: Hrvatski znanstveni zbornik, vol. 2. Zagreb: Matica hrvatska, 1971. vatske, 1989. . Bespuća povijesne zbiljnosti. Zagreb: Nakladni zavod Matice hr. Nacionalno pitanje u suvremenoj Europi. Zagreb: Nakladni zavod Matice hrvatske, 1990.

. Horrors of War: Historical Reality and Philosophy, trans. Katarina Mijatović. New York: M. Evans \& Co., 1996. 